\section{Response to eLetter: 'Infections in giant cell arteritis and therapeutic implications' by Moiseev et al}

We thank Professor Moiseev and colleagues for showing their interest in our work. ${ }^{12}$ While we agree that our study does not completely refute the link between varicella zoster virus (VZV) and giant cell arteritis (GCA), we feel that stronger evidence of a link between VZV and GCA are needed before clinical trials are conducted in which patients with GCA are given antiviral therapy. If $\mathrm{VZV}$, whether clinically overt, subclinical or latent, triggers the onset of GCA, we would have expected a stronger association between herpes zoster and GCA compared with the association of other infections with GCA. Although outside the scope of our study, we agree that the risk of infection following the institution of immunosuppressive therapy, including biological agents, for GCA is extremely important and needs to be further defined.

Rennie L Rhee, ${ }^{1}$ Peter C Grayson, ${ }^{2}$ Peter A Merkel, ${ }^{1}$ Gunnar Tomasson ${ }^{3}$

${ }^{1}$ Department of Rheumatology, Perelman School of Medicine at the University of Pennsylvania, Philadelphia, Pennsylvania, USA

${ }^{2}$ National Institutes of Health/NIAMS, Bethesda, Maryland, USA

${ }^{3}$ University of Iceland, Reykjavik, Iceland
Correspondence to Dr Rennie L Rhee, Department of Rheumatology, Perelman School of Medicine at the University of Pennsylvania, Philadelphia, PA 19104, USA; rennie.rhee@uphs.upenn.edu

Competing interests None declared.

Provenance and peer review Commissioned; internally peer reviewed.

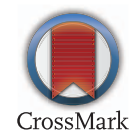

To cite Rhee RL, Grayson PC, Merkel PA, et al. Ann Rheum Dis 2017;76:e30.

Received 21 December 2016

Accepted 25 December 2016

Published Online First 17 January 2017

\section{Linked}

http://dx.doi.org/10.1136/annrheumdis-2016-210955

Ann Rheum Dis 2017;76:e30. doi:10.1136/annrheumdis-2016-210976

\section{REFERENCES}

1 Rhee RL, Grayson PC, Merkel PA, et al. Infections and the risk of incident giant cell arteritis: a population-based, case-control study. Ann Rheum Dis 2017;76:1031-5.

2 Moiseev S, Novikov P, Smitienko I, et al. Giant cell arteritis, infections and biologics. Ann Rheum Dis 2017;76:e29. 